\title{
PERALATAN DAPUR TRADISIONAL SEBAGAI WARISAN KEKAYAAN BUDAYA BANGSA INDONESIA (Traditional of Kitchen Equipment as Cultural Heritage Richness of Indonesia Nation)
}

\section{Lilyk Eka Suranny}

Kantor Litbang IPTEK Kabupaten Wonogiri, Brigjen Katamso No.2, Kec. Wonogiri, Wonogiri, Jawa Tengah 57612, Telepon: (0273) 321155, e-mail: lilik_fd@yahoo.com

\section{INFO ARTIKEL}

Histori artikel:

Diterima 20 April 2015

Direvisi 27 April 2015

Disetujui 4 Mei 2015

\section{Keywords:}

traditional kitchen equipment,

nations rich heritage,

tradition value

\section{Kata kunci:}

peralatan dapur tradisional, warisan kekayaan bangsa, nilai tradisi

\begin{abstract}
Traditional kitchen equipment has existed since prehistoric people began to recognize the farming. Along with the development of science and technology, the use of traditional kitchen equipment is being abandoned by the community. Therefore it is necessary to attempt for preserve this traditional kitchen equipment as one of the nations rich heritage. This paper will describe some traditional kitchen equipment, its benefits and the existence in community. Data was collected using observation, interviews and literature study. This study used a qualitative descriptive method. Some traditional kitchen equipment that was found in this study, among others furnace, cormorant, cauldron, wajan, jugs, coconut grated, crock, irus, centong, as well as pestle and mortar. The benefits derived from the use of traditional kitchen equipment is to have a distinctive flavor, safer and environmentally friendly, more economical and preserve the traditions of the ancestors.
\end{abstract}

\section{PENDAHULUAN}

Kebudayaan nasional Indonesia berasal dari gabungan berbagai kebudayaan daerah. Kebudayaan daerah merupakan suatu kebiasaan dalam wilayah/daerah tertentu yang diwariskan secara turun-temurun oleh generasi terdahulu ke generasi berikutnya. Ada berbagai macam kebudayaan daerah antara lain lagu daerah, tarian daerah, rumah adat, peralatan pertanian, peralatan memasak, dan sebagainya. Salah satu unsur kebudayaan daerah yang diangkat dalam tulisan ini adalah peralatan dapur tradisional. Dinamakan peralatan dapur karena lokasi penggunaannya di dapur yaitu untuk memasak. Peralatan dapur tradisional antara satu daerah dengan daerah lain pada umumnya banyak kesamaan, yang berbeda yaitu dalam penamaan atau penyebutannya saja. Peralatan dapur tradisional muncul dari proses peradapan manusia dalam mempertahankan kehidupannya. Peralatan dapur tersebut dibuat untuk mengolah bahan makanan dari bahan mentah menjadi bahan makanan yang siap saji. Setiap rumah tinggal memiliki dapur sehingga peralatan dapur 
merupakan bagian mendasar bagi setiap keluarga.

Peralatan dapur tradisional sudah ada sejak jaman nenek moyang. Manusia mulai mengenal seni kerajinan termasuk pembuatan peralatan dapur sejak mengenal tradisi bercocok tanam (Sartono, 1975: 174). Berbagai bukti arkeologis mengenai penggunaan peralatan dapur tradisional pada masa lampau yakni penemuan artefak (benda-benda sejarah) berupa kreweng atau pecahan gerabah. Menurut para arkeolog yang menelitinya, kreweng berasal dari pecahan peralatan untuk memasak ada pula yang berasal dari peralatan rumah lainnya. Faktor yang menyebabkan gerabah banyak ditemukan pada situs-situs arkeologi karena sifat gerabah yang tahan dari pelapukan, sehingga mudah pecah akan tetapi tidak hancur, relatif tahan air dan tahan panas api (Ambar, 2008:1). Penelitian mengenai peralatan memasak tradisional pernah dilakukan oleh Septiana Astuti pada tahun 2012, melakukan kajian mengenai Makna Lesikal Nama Peralatan Rumah Tangga Tradisional di Pasar Gedhe Klaten, dari penelitian ini diperoleh nama-nama peralatan rumah tangga tradisional di Pasar Gedhe Klaten beserta fungsinya yang terdiri dari 44 jenis yaitu peralatan rumah tangga tradisional yang terbuat dari tanah liat, bambu, kayu, batu, dan besi. Penelitian lainnya yaitu penelitian mengenai Peralatan Dapur Tradisional Aceh oleh Nasruddin Sulaiman, dkk pada tahun 1993/1994, dari penelitian tersebut mendiskripsikan nama,jenis, bentuk,bahan dan fungsi peralatan dapur tradisional Aceh.
Selain untuk memenuhi kebutuhan rumah tangga keluarga, peralatan dapur juga digunakan untuk mendukung kegiatan dalam skala besar. Sejarah bangsa Indonesia mencatat betapa pentingnya logistik , diantaranya peralatan dapur dalam mendukung strategi perang. Ini mengenai sejarah penyerangan Kerajaan Mataram terhadap Batavia yang pada saat itu dikuasai oleh Belanda. Dalam penyerangan tersebut, Kerajaan Mataram mengalami kekalahan yang disebabkan oleh kurangnya bahan makanan (logistik) peperangan. Kekalahan penyerangan pertama ini menjadi pembelajaran bagi Kerajaan Mataram sehingga pada penyerangan kedua logistik dipersiapkan lebih matang termasuk peralatan memasak yang digunakannya. Sejarah Kerajaan Mataram ini membuktikan betapa besar peran logistik dalam peperangan selain persenjataan dan strategi perang (Poesponegoro, 1984:67).

Sejalan dengan perkembangan ilmu pengetahuan dan teknologi, peralatan dapur tradisional sudah mulai ditinggalkan dan digantikan oleh peralatan dapur modern. Ada berbagai alasan masyarakat terhadap beralihnya penggunaan peralatan memasak tradisional menjadi peralatan memasak yang modern. Pertama, mereka yang menggunakan peralatan memasak modern menilai lebih praktis, awet dan mudah penggunaanya. Kedua, bentuknya lebih bagus dengan balutan teknologi canggih. Ketiga, adanya perubahan status sosial dalam masyarakat. Masyarakat yang memiliki penghasilan berlebih akan 
berusaha mendapatkan berbagai jenis peralatan modern untuk memudahkan mereka dalam menyelesaikan pekerjaan. Keempat, anggapan bahwa penggunaan peralatan tradisional dapat mengesankan bahwa pemakainya ketinggalan jaman, kuno, dan sebagainya. Jika unsur budaya daerah yang berupa peralatan dapur tradisional ini tidak dilestarikan, maka generasi yang akan datang tidak dapat menikmati ataupun sekedar melihatnya sebagai warisan kekayaan budaya bangsa Indonesia. Dengan demikian permasalahan utama yang akan diungkapkan dalam penelitian ini adalah bagaimana upaya untuk melestarikan peralatan dapur tradisional melalui identifikasi jenis dan fungsinya serta manfaatnya bagi masyarakat. Tujuan penelitian ini adalah mengetahui jenis dan fungsi peralatan dapur tradisional serta manfaat penggunaannya bagi masyarakat saat ini.

\section{METODE PENELITIAN}

Penelitian ini merupakan penelitian deskriptif melalui pendekatan kualitatif. Menurut Nawawi (1983:64), metode penelitian deskriptif memiliki 2 ciri pokok yaitu memusatkan perhatian pada masalah yang diteliti dan menggambarkan fakta-fakta tentang masalah yang sedang diteliti diiringi dengan interpretasi rasional. Bagdan dan Taylor dalam Moleong (2003:3), menyatakan bahwa penelitian kualitatif merupakan penelitian yang menghasilkan data deskriptif berupa kata-kata tertulis atau lisan dari orang-orang dan perilaku yang diamati. Teknik pengumpulan data dilakukan melalui pengamatan dalam masyarakat (observasi), wawancara pada beberapa informan, dokumentasi dan studi kepustakaan. Pengamatan dilakukan pada beberapa daerah terutama di pulau Jawa yang masih menggunakan peralatan memasak tradisional. Informan dalam penelitian ini dipilih menggunakan teknik snowball sampling dengan bantuan key-informan pada beberapa orang yang masih menggunakan peralatan memasak tradisional. Selanjutnya dilakukan analisis data berdasarkan fakta dan data yang ditemukan untuk menguraikan beberapa jenis dan fungsi peralatan dapur tradisional, manfaat penggunaannya serta keberadaan di dalam masyarakat saat ini.

\section{HASIL DAN PEMBAHASAN}

\section{Peralatan dapur dan fungsinya}

Keberadaan berbagai jenis peralatan dapur tradisional ini dapat kita temukan pada masyarakat di daerah pedesaan. Kebanyakan kehidupan masyarakat desa masih memegang teguh tradisi nenek moyang termasuk dalam penggunaan peralatan dapur tradisional. Beberapa acara yang digelar di pedesaan masih menggunakan peralatan dapur tradisional misalnya saja hajatan, upacara adat, pengajian dan sebagainya. Teknologi pembuatan peralatan dapur tradisional sangat sederhana. Bahan baku yang digunakan tersedia di alam, misalnya tanah liat, bambu, kayu, ataupun batu. Berdasarkan hasil penelitian yang dilakukan beberapa jenis dan fungsi dari peralatan dapur tradisional dapat diuraikan sebagai berikut: 


\section{Tungku}

Tungku merupakan bagian yang paling utama dalam dapur tradisional. Dapur belum dapat berfungsi jika di dalamnya belum ada tungku. Tungku merupakan salah satu komponen dalam proses pengolahan makanan (Aristanti, 2001: 78). Ada beberapa penyebutan lokal untuk tungku, diantaranya orang Jawa menyebutnya pawon, dhingke/dan anglo. Tungku dibuat secara sederhana dan diletakkan secara permanen di dalam dapur. Tungku terbuat dari batu cadas, tanah liat ataupun dari batu bata. Bahan bakar untuk memasak menggunakan tungku adalah kayu bakar. Desain tungku berbentuk persegi panjang dengan panjang kurang lebih $95 \mathrm{~cm}$, lebar $60 \mathrm{~cm}$ dan tinggi $30 \mathrm{~cm}$ dari permukaan lantai, terdapat lubang pembakaran diatas tungku berdiameter $30 \mathrm{~cm}$ yang berfungsi untuk meletakkan alat memasak (Mulyono, 2009: 2). Tungku dibuat tertutup disekelilingnya kecuali pada lubang tempat memasukkan kayu bakar dan bagian atas tungku agar nyala api yang dihasilkan dapat digunakan untuk memasak. Dimensi ketinggian tungku jauh dibawah posisi siku penggunanya sehingga mengharuskan pengguna untuk memakainya dengan posisi duduk atau berdiri sambil membungkuk (Mulyono, 2009: 1). Bentuk tungku ada dua macam disesuaikan dengan kebutuhan pemakainya, yaitu tungku tunggal dan tungku ganda. Berdasarkan hasil wawancara dengan informan, sebagai berikut: "Pertama, tungku (pawon) tunggal, artinya tungku tersebut hanya dapat digunakan untuk meletakkan satu alat masak saja, yang kedua adalah tungku ganda digunakan untuk meletakkan dua alat masak sekaligus. Pada tungku (pawon) ganda ini, lubang tempat memasukkan kayu bakar hanya satu dibagian tengah sedangkan bagian atas terdiri atas dua lubang yang digunakan sebagai tempat meletakkan alat memasak. Antara kedua lubang tempat meletakkan alat memasak tersebut tidak disekat sehingga api menyebar pada dua arah. Ada juga tungku yang terbuat dari batu bata yang disusun sejajar dua baris yang diletakkan melintang yang disebut dhingkel" (Wawancara Bapak Marno, 12 Juni 2014).

Anglo terbuat dari tanah liat, bahan bakarnya adalah arang. Anglo ini biasanya berbentuk seperti silinder dengan bagian bagian bawah tertutup rapat dan bagian atas berbentuk bundar yang diatasnya diberi tonjolan sebagai tempat untuk meletakkan alat memasak. Anglo juga memiliki bagian-bagian yang memiliki fungsi berbeda-beda yaitu sarangan anglo dan cangkem anglo (mulut anglo) (Sumintarsih, 2006:20). Ruang disekitar bagian yang menonjol ini berfungsi sebagai tempat aliran udara dan api dari lubang bawah. Pada bagian tengahnya yaitu tempat bara api terdapat lubang-lubang kecil yang disebut sarangan. Fungsinya sebagai tempat aliran udara yang berasal dari arang yang dikipaskan dari lubang bagian bawah. Pada lubang bagian bawah ada satu lubang besar yang dinamakan mulut anglo. Apabila mulut 
anglo dikipasi maka udara akan masuk lewat lubang sarangan kemudian naik keatas pada tempat bara api sehingga bara api akan menyala. Arang yang digunakan sebagai bahan bakar anglo hendaknya merupakan arang yang berkualitas baik sehingga akan menghasilkan bara api yang bertahan lama dan tidak mudah menjadi abu. Arang yang berkualitas baik ini biasanya berasal dari kayu-kayu yang keras. Arang berasal dari kayu yang dibakar dan mengalami proses pendinginan. Masyarakat yang masih menggunakan anglo ini mendapatkan bahan bakar yang berupa arang dari pedagang arang ataupun mereka membuatnya sendiri. Ada berbagai bentuk dan ukuran dari anglo ini, ada yang besar, sedang ataupun kecil disesuaikan dengan kebutuhan. Untuk lebih detailnya berikut wawancara dengan informan: "Anglo yang berukuran besar biasanya untuk memasak dalam skala besar, misalnya pada saat ada hajatan. Anglo ukuran sedang biasanya digunakan untuk pemakaian rumah tangga dan anglo dengan ukuran kecil biasanya dipergunakan untuk membakar malam sebagai bahan baku dalam membatik, membakar dupa/kemenyan yang merupakan bagian dari peralatan prosesi upacara adat Jawa, ataupun juga untuk memasak kue serabi" (Wawancara dengan ibu Sri, 12 Juni 2014).

Selain digunakan untuk memasak makanan, tungku ini kadang digunakan oleh masyarakat di pedesaan untuk mengusir rasa dingin dengan menghangatkan badan didekat bara api pada tungku (http://tembi.net). Memasak dengan menggunakan bahan bakar dari kayu bakar ataupun arang akan menghasilkan limbah yang berupa abu. Pada jaman dulu nenek moyang kita telah memanfaatkan limbah abu tersebut untuk berbagai keperluan. Ada yang menggunakan sebagai bahan campuran obat tradisional, sebagai pasta gigi alami dan sebagai abu gosok untuk mencuci perkakas dapur. Ramuan obat yang berasal dari abu dapur sering digunakan oleh masyarakat pada jaman dulu sebagai obat penurun demam pada anak-anak terutama bayi, juga dapat mempercepat proses keringnya pusar bayi yang baru lahir. Abu dapur juga digunakan sebagai pasta gigi alami yang berfungsi untuk memutihkan gigi (http://melayuonline. com). Ibu-ibu rumah tangga pada jaman dulu telah memanfaatkan abu gosok untuk membersihkan nodanoda membandel pada perkakas dapur terutama noda hitam bekas memasak. Perkakas dapur akan menjadi bersih karena adanya kandungan kalium di dalam abu gosok. Penjelasan ilmiahnya yaitu kalium pada abu dapur yang bereaksi dengan air pada saat pencucian akan menghasilkan kalium hidroksida yang bersifat basa sehingga dapat menyebabkan kotoran/noda hitam tersebut dapat terangkat (http:// penjaskesehatan.blogspot.com).

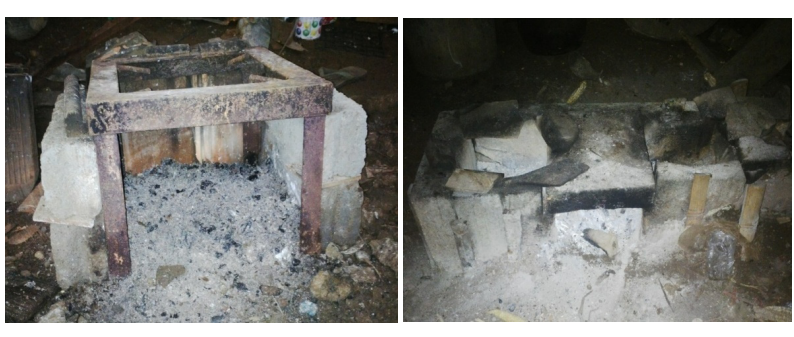

Gambar 1. Tungku tunggal (kiri) dan tungku ganda (kanan (dokumentasi Lilyk) 


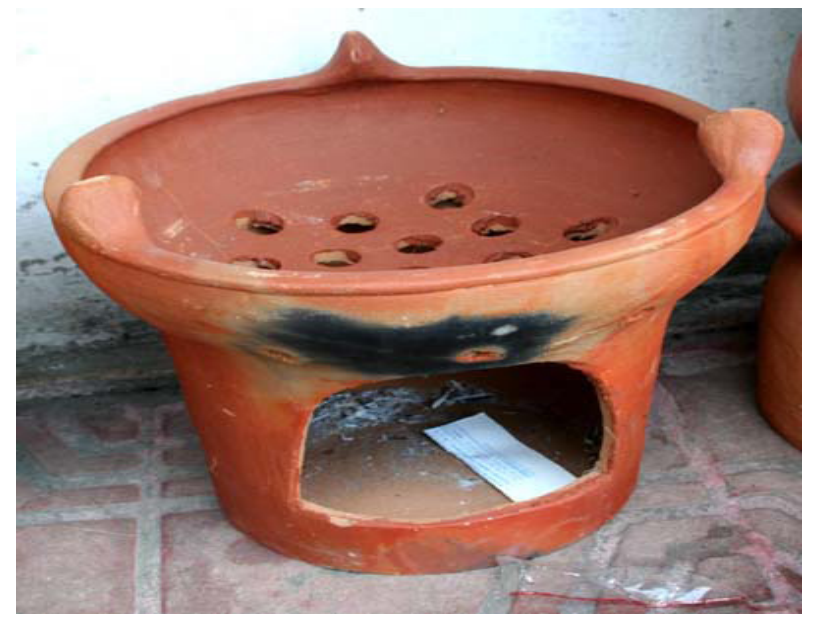

Gambar 2. Anglo Sumber:(http://tembi.net/ensiklopedi-anekarupa/anglo-si-kompor-tanah-liat)

\section{Dandang}

Dandang merupakan alat memasak tradisional yang sebagian besar difungsikan untuk menanak nasi. Selain untuk menanak nasi, dandang oleh masyarakat pedesaan juga digunakan untuk menanak makanan seperti singkong, ketela rambat, dan umbiumbian sejenisnya. Dandang terbuat dari tembaga ,warnanya kuning keemasan dan bentuknya seperti topi panjang yang terbalik. Pada masyarakat Aceh, dandang disebut juga kanet dangdang atau sangku tanoh, masyarakat Gayo menyebutnya kukusen (Sulaiman, 1993/1994:28). Cara menanak nasi dengan menggunakan dandang adalah dengan mengukusnya. Untuk menanak nasi selain menggunakan dandang perlu perlengkapan lain misalnya kukusan, kekeb, solet dan penyaton. Kukusan bentuknya kerucut, diletakkan ke dalam dandang dengan bagian yang lancip/ ujungnya berada dibawah. Penyaton diletakkan didalam kukusan pada bagian ujungnya. Penyaton ini difungsikan untuk menahan agar nasi yang ditanak pada bagian bawah tidak terkena air yang dimasukkan dalam dandang. Solet digunakan untuk mengaduk nasi selama ditanak agar hasilnya merata. Solet terbuat dari bambu ataupun kayu. Sedangkan kekeb berfungsi untuk menutup bagian atas kukusan agar cepat matang dan melindungi nasi yang ditanak dari kotoran. Kekeb ini ada yang terbuat dari bambu ataupun dari tanah liat (http:// dermaji.desa.id). Pada masyarakat pedesaan menanak nasi menggunakan dandang dilakukan padaacara-acarayang besar misalnya hajatan karena dengan memakai dandang daya tampung beras yang akan dimasak lebih besar. Namun penggunaan dandang menjadi semakin langka dijumpai. Saat ini masyarakat lebih banyak menggunakan peralatan memasak modern seperti rice cooker ataupun dandang aluminium. Padahal menanak nasi menggunakan dandang tembaga dinilai lebih enak karena nasi yang dimasak menggunakan dandang lebih tanak dan baunya lebih sedap. Selain itu dandang tembaga lebih awet dan tidak mudah bocor karena lapisannya lebih tebal. Pada masyarakat jaman dulu pemakaian dandang kental dengan berbagai mitos yang menyertainya. Sebagai contoh di Jawa mitos yang menyertai penggunaan dandang yakni dapat memancing suara tangisan bayi yang baru lahir tanpa tangisan dan memanggil orang yang jauh dari kita agar cepat pulang. Caranya yakni dengan memanggil nama si bayi lewat lubang dandang. Hal yang sama juga dilakukan untuk memanggil orang agar cepat pulang yakni dengan memanggil nama orang tersebut dalam lubang dandang (Anonim, 2013). Di Daerah Parangtritis dan Imogiri Bantul mitos yang menyertai penggunaan 
dandang adalah apabila menggulingkan dandang pada saat menanak nasi maka harus diruwat agar tidak dimakan Bethara Kala (Sumintarsih dkk, 1990/1991: 45).
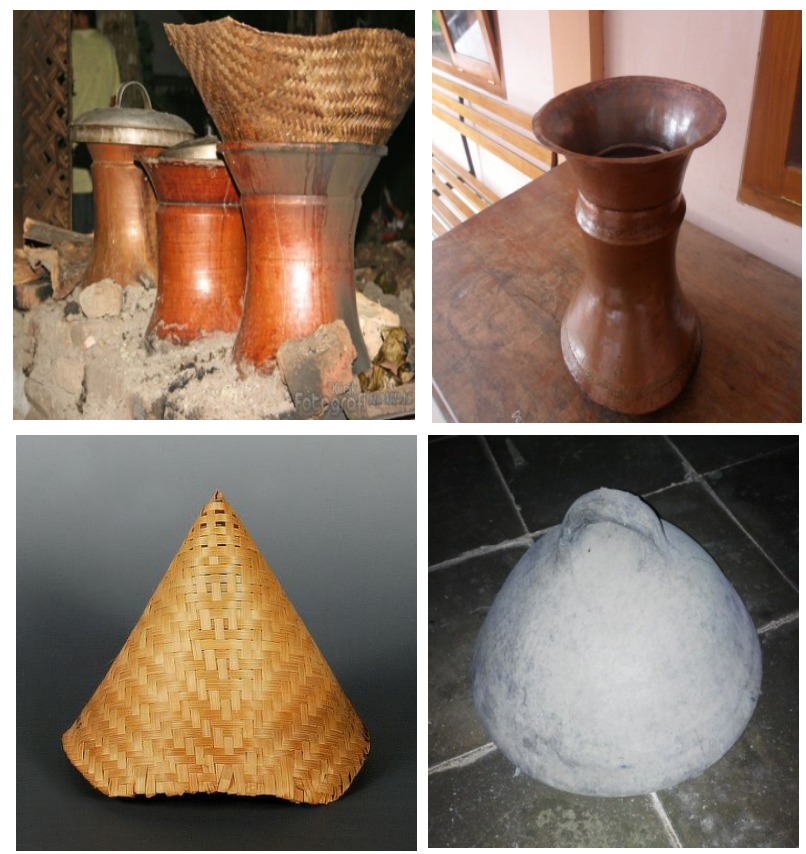

Gambar 3. Dandang dan seperangkat alat untuk mengukus nasi (kukusan dan kekeb) Sumber: http://bebibluu.blogspot. com/2014_06_01_archive.html

\section{Belanga}

Merupakan peralatan dapur tradisional yang bahan bakunya berasal dari tanah liat. Bentuknya bundar dengan mulut besar, antara bagian atas dan bawah sama besar kadang di desain dengan dua kuping sebagai pegangan ataupun tanpa pegangan dibagaian atasnya. Di Jawa belanga lebih umum disebut dengan kuali sedangkan di daerah Aceh belanga sering disebut dengan blangong (Sulaiman, 1993/1994:19). Belanga digunakan sebagai tempat untuk menanak nasi, memasak sayur, memanggang ayam, merebus singkong dan hasil bumi lainnya ataupun juga merebus air. Belanga dibuat dengan berbagai ukuran dari yang besar, sedang dan ukuran kecil sesuai kebutuhan pemakainya. Belanga dapat diperoleh di beberapa pasar tradisional. Dahulu alat-alat memasak tradisional dapat diperoleh dengan sistem barter selain dibeli menggunakan uang. Biasanya mereka menukarkan barangbarang tertentu misalnya saja padi, beras ataupun barang lainnya untuk ditukar dengan peralatan dapur yang diinginkan (Sulaiman, 1993/1994:19). Apabila telah rusak atau bocor belanga tidak dapat diperbaiki dan harus digantikan dengan yang baru.

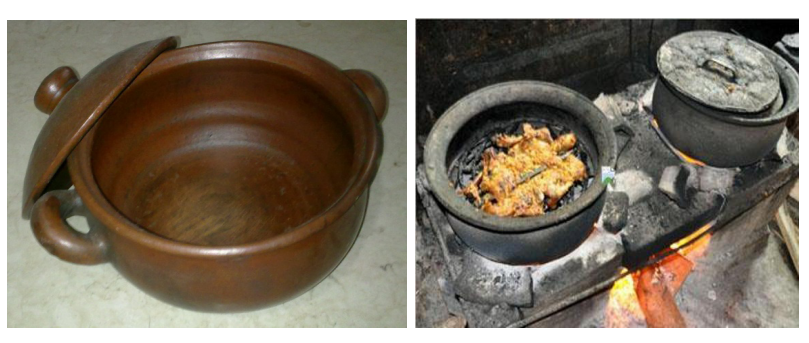

Gambar 4. Kuali tanah liat (dokumentasi Lilyk)

\section{Wajan}

Salah satu peralatan dapur yang memegang peranan penting dalam kebutuhan rumah tangga adalah wajan. Wajan merupakan salah satu peralatan dapur yang digunakan untuk menggoreng, memasak sayur, menyangrai kacangkacangan ataupun menumis makanan. Masyarakat di daerah Aceh menyebut wajan dengan blangong sudu (Sulaiman, 1993/1994:33). Pada jaman dahulu wajan yang digunakan untuk memasak terbuat dari tanah liat ataupun besi. Namun sekarang sudah jarang sekali penggunaan wajan tanah liat atau besi untuk memasak, digantikan dengan wajan aluminium ataupun stainless steel. Wajan tradisional dari tanah liat penggunaannya masih terbatas untuk menyangrai dan memasak sayur. Untuk menggoreng masyarakat jaman dulu menggunakan wajan besi. Wajan besi warnanya hitam 
dan lebih berat jika dibandingkan dengan wajan tanah liat. Apabila tidak dirawat dengan baik biasanya wajan yang terbuat dari besi ini mudah berkarat. Wajan bentuknya cekung mirip parabola yang dibagian atasnya didesain ada dua telinga yang difungsikan sebagai pegangan. Ukurannya bermacammacam disesuaikan dengan kebutuhan pemakainya. Wajan dan belanga bentuknya hampir sama, hanya saja untuk belanga tingkat kecekungannya lebih dalam.

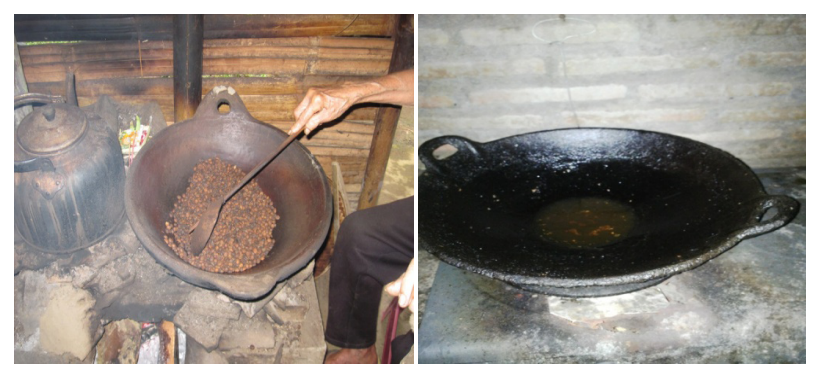

Gambar 5. Menyangrai kacang menggunakan wajan tanah liat (kiri), wajan besi (kanan (dokumentasi Lilyk)

\section{Kendi}

Kendi adalah tempat atau wadah air minum yang terbuat dari tanah liat. Kata kendiberasaldaribahasaSansekertayakni kundika yang artinya wadah air minum. Pada beberapa daerah di Indonesia kendi ini mempunyai penyebutan yang berbeda-beda meskipun fungsinya sama. Di Sumatera Barat disebut labu tanah, di Batak disebut kandi, di Bali disebut kundi atau caratan, di Sulawesi Selatan disebut busu, di Aceh disebut geupet bahlaboh dan di Lampung disebut hibu. Di Jawa kendi mulai di kenal sejak abad ke-9 dengan ditemukannya relief-relief di Candi Borobudur pada teras Kamadhatu (http://id.wikipedia.org). Bentuk kendi adalah bulat pada badannya, terdapat leher yang fungsinya sebagai pegangan dan diberi corong kecil pada salah satu bagiannya untuk menuang air dari dalam kendi. Pada bagian atas leher kendi diberi lubang yang agak besar untuk mengisi air minum ke dalam kendi.

Kendi juga dipergunakan dalam upacara adat dan sebagai pelengkap sesaji. Di Jawa kendi digunakan dalam acara perkawinan karena dianggap suci dan menyejukkan yang menjadi simbul perkawinan yang sempurna. Dalam acara tersebut mempelai wanita membasuh kaki mempelai pria dengan air kendi. Ini melambangkan kesetiaan seorang istri kepada suaminya. Selain upacara pernikahan, di Jawa Tengah khususnya kendi dipergunakan pada upacara pemakaman. Pada acara pemakaman jenasah, kendi yang berisi air disiramkan diatas kuburan. Tradisi ini dipercaya masyarakat untuk menyejukkan arwah yang telah meninggal. Di Bali kendi juga dipergunakan pada acara-acara keagamaan (http://id.wikipedia.org). Masyarakat pada jaman dulu percaya bahwa air yang dimasukkan dalam kendi berkhasiat untuk kesehatan. Hal tersebut ternyata dapat dibuktikan secara ilmiah bahwa air putih yang disimpan dalam kendi jauh lebih sehat dan segar daripada air minum yang dimasukkan dalam teko plastik, botol kaca ataupun logam. Kendi terbuat dari tanah liat sehingga poripori tanah akan menyebabkan udara luar yang mengandung oksigen mampu menembus masuk ke dalam kendi. Inilah yang menyebabkan air di dalam kendi terasa segar dan sejuk karena kaya akan kandungan oksigen. 


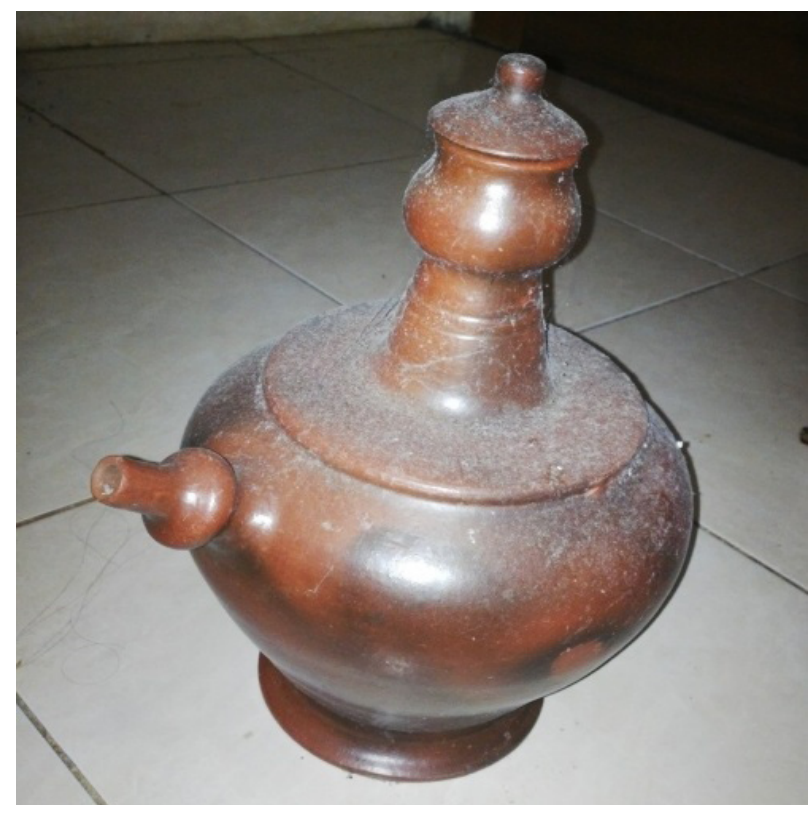

Gambar 6. Kendi (dokumentasi Lilyk)

\section{Parutan Kelapa}

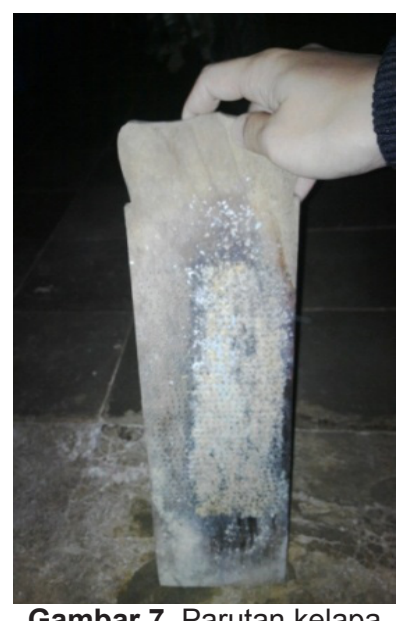

Gambar 7. Parutan kelapa dari kayu

(dokumentasi Lilyk)

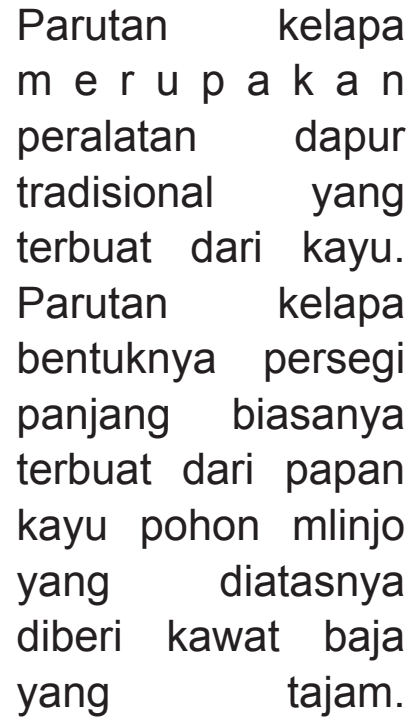

Penggunaan kayu pohon mlinjo ini karena pohon mlinjo mengandung minyak yang apabila bercampur dengan parutan kelapa menjadikan rasanya lebih enak. Parutan kelapa tradisional ini dibuat dengan menempelkan kawat baja yang telah dipotong pada papan kayu sebagai bahan pembuat parutan kelapa. Kawat baja tersebut dipukul sampai menancap pada papan kayu. Penggunaan parutan kelapa tradisional saat ini dapat ditemukan pada masyarakat pedesaan. Selain dari kayu ada juga parutan kelapa manual yang terbuat dari bahan seng. Saat ini parutan kelapa tradisional sudah jarang digunakan. Masyarakat lebih memilih menggunakan mesin pemarut kelapa ataupun blender. Adapula yang mencari kepraktisan dengan membeli santan kelapa dalam kemasan.

\section{Tempayan}

Tempayan atau genthong dalam bahasa Jawa, berfungsi sebagai wadah untuk menyimpan persediaan air bersih di dapur. Tempayan terbuat dari tanah liat, bentuknya bulat cembung mengecil kebawah dengan lubang yang cukup besar pada bagian atasnya yang fungsinya untuk memasukkan air bersih. Tempayan dibuat dengan beberapa ukuran yang besar, sedang maupun yang kecil sesuai dengan kebutuhannya. Selain digunakan untuk menyimpan air, tempayan juga dapat digunakan untuk menyimpan beras. Pada masyarakat di daerah Aceh, tempayan yang berukuran besar dinamakan peudeuna sedangkan tempayan berukuran kecil dinamakan guroe. Di Aceh tempayan ini juga digunakan untuk menyimpan minyeuk brok (jenis minyak kelapa yang dihasilkan dengan sistem pengolahan tradisional), tempat menyimpan asam sunti, tempat menyimpan cuka jrok (cuka aren) dan cuka nipah (Sulaiman, 1993/1994:30). Pada saat ini tempayan banyak digunakan untuk hiasan pada taman saja karena masyarakat banyak menggunakan tampungan air yang berbahan baku plastik ataupun stainless steel. 


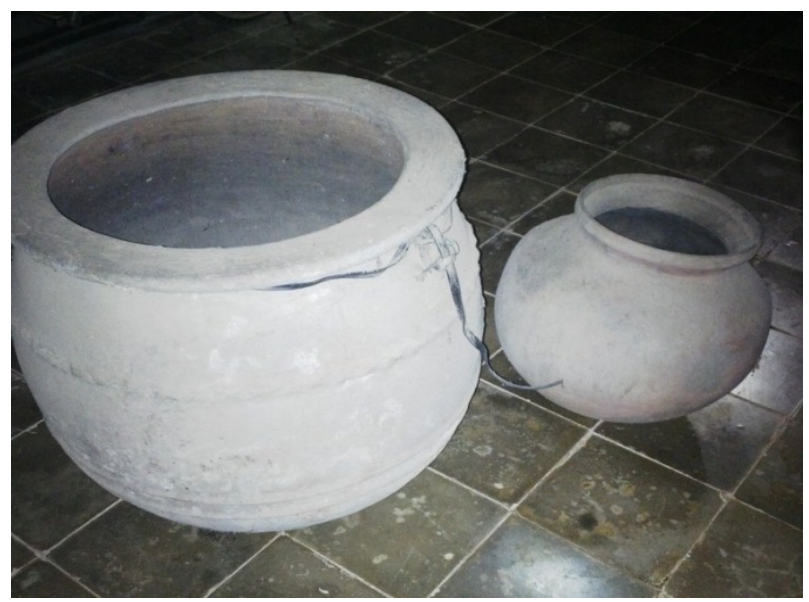

Gambar 8. Tempayan dengan ukuran besar dan kecil (gentong) (dokumentasi Lilyk)

\section{Irus dan centong}

Irus merupakan alat memasak tradisional yang berfungsi untuk mengaduk sayuran ketika sedang memasak ataupun untuk mengambil makanan yang berkuah seperti sup. Irus terbuat dari tempurung kelapa yang dihaluskan dan memiliki pegangan (gagang). Bentuknya hampir menyerupai sebuah sendok dengan tangkai lebih panjang, masyarakat di Aceh menyebutnya dengan aweuek (Sulaiman, 1993/1994:25). Pada umumnya tempurung kelapa yang digunakan berdiameter sekitar $10 \mathrm{~cm}$, tangkainya lebih panjang dari tangkai sendok, pada umumnya sekitar $25-30 \mathrm{~cm}$. Tangkainya terbuat dari bambu atau batang yang dibentuk dengan sistem merautnya, bagian ujungnya yang kecil dimasukkan kedalam tempurung yang telah diberi lubang (Sulaiman, 1993/1994:25). Penggunaan irus tempurung kelapa ini semakin jarang karena hadirnya irus dari bahan stainles stell dan aluminium. Centong merupakan perkakas rumah tangga yang berfungsi untuk mengambil nasi ataupun mengaduk nasi pada saat memasak. Centong tradisional terbuat dari kayu. Saat ini irus dan centong tidak hanya digunakan untuk memasak saja, ada yang menggunakannya untuk sovenir pernikahan yang unik.
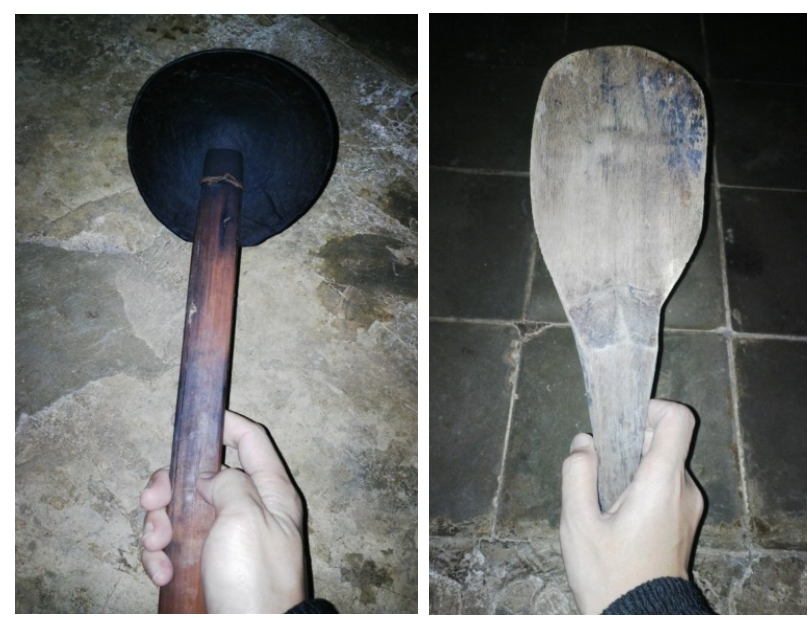

Gambar 9. Irus dan centong (dokumentasi Lilyk)

\section{Cobek dan Ulekan}

Cobek dan ulekan merupakan bagian dari peralatan dapur yang sampai sekarang masih banyak digunakan oleh masyarakat. Orang Jawa menyebut cobek dan ulekan dengan nama lemper dan munthu. Masyarakat Aceh menyebut cobek dengan sebutan batee lada dan menyebut ulekan dengan sebutan ulakulak (Sulaiman, 1993/1994:49). Alat ini berfungsi untuk menghaluskan bumbu, menumbuk, melumatkan makanan dan membuat sambal. Cobek biasanya terbuat dari batu alam ataupun tanah liat, sedangkan ulekan ada yang terbuat dari batu ataupun kayu. Namun dari berbagai bahan yang digunakan untuk membuat cobek dan ulekan paling banyak diminati adalah yang berasal dari batu karena lebih kuat dan awet. Cobek bentuknya bulat agak cekung dengan ukuran yang bermacam-macam disesuai kebutuhan pemakainya. Masyarakat lebih menyukai 
membuat sambal ataupun melumatkan bumbu menggunakan cobek dan ulekan karena dinilai lebih enak daripada digiling menggunakan blender. Bagi para pecinta sambal, sambal yang dibuat menggunakan cobek dan ulekan akan terasa lebih nikmat. Hal inilah yang digunakan oleh restoran-restoran untuk meningkatkan daya tarik konsumen yakni dengan menyajikan sambal menggunakan cobek kecil. Ada sebagian masyarakat Jawa yang masih memegang teguh tradisi menggunakan cobek dan ulekan sebagai salah satu budaya dalam suatu pernikahan. Berikut kutipan wawancara dengan informan, "Orang tua memberikan bekal kepada kedua mempelai berupa cobek dan ulekan yang dalam hal ini berisi pesan kepada mempelaiuntukdapatsaling bekerjasama dan saling menjaga keharmonisan dalam menjalani kehidupan mereka yang baru" (Wawancara dengan bapak Tunggal, tanggal 15 Januari 2015). Sebuah pesona dari cobek dan ulekan sebagai peninggalan sejarah yang biasanya hanya digunakan di dapur ternyata memiliki nilai budaya sebagai salah satu kekayaan bangsa.

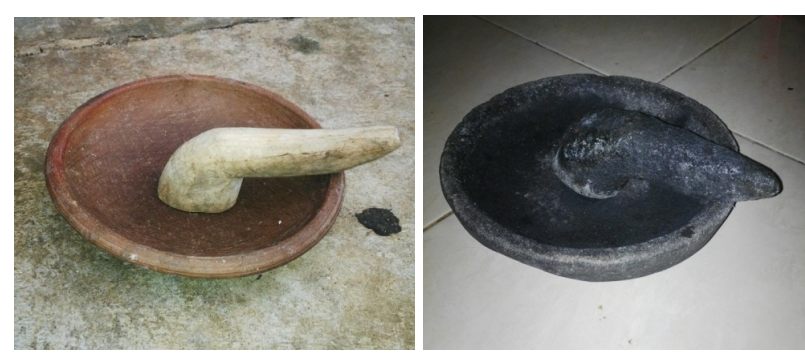

Gambar 10. Cobek dan ulekan kayu (kiri), cobek dan ulekan batu (kanan) (dokumentasi Lilyk)

\section{Manfaat penggunaan peralatan me- masak tradisional}

Seiring dengan perkembangan jaman, penggunaan peralatan dapur tradisional ini semakin ditinggalkan oleh masyarakat. Banyak masyarakat yang telah beralih pada peralatan memasak yang lebih modern. Mereka beranggapan bahwa peralatan memasak modern lebih praktis, awet, bersih dan sebagainya. Padahal apabila ditelusurlebihjauh banyakmanfaat yang dapat diperoleh dari penggunaan peralatan dapur tradisional ini. Menurut Setyawan (2009:20) bahwa peralatan dapur merupakan suatu kerajinan rakyat yang mempunyai nilai seni dan budaya yang tinggi. Berikut penulis mencoba menguraikan beberapa manfaat yang dapat diambil dari penggunaan peralatan dapur tradisional yaitu:

\section{a. Memiliki cita rasa yang khas}

Masyarakat yang masih setia menggunakan peralatan dapur tradisional dalam memasak beranggapan bahwa rasa yang ditimbulkan dari hasil masakan lebih nikmat. Makanan yang dimasak menggunakan anglo ataupun tungku tradisional dengan bahan bakar arang dan kayu akan menimbulkan cita rasa yang berbeda apabila dibandingkan dengan makanan yang dimasak menggunakan kompor gas ataupun kompor listrik. Misalnya saja gudeng dan bakmi rebus yang dimasak menggunakan anglo dan kuali dari tanah liat rasanya lebih nikmat daripada dimasak menggunakan kuali ataupun wajan dari aluminium dan stainless stell. Tanah liat dapat menghantarkan panas namun tidak sebaik aluminium ataupun stainless stell. Pada saat memasak, kuali tanah liat menangkap panas dari api tungku secara perlahan sehingga proses pematangan makanan terjadi secara bertahap. Suhu panas yang dihasilkan dari arang dijaga agar stabil sehingga masakan lebih 
matang maksimal. Senyawa yang ada dalam kayu bakar ataupun arang ini akan keluar melalui asap pembakaran sehingga dapat bercampur dengan masakan menghasilkan aroma yang khas. Asap ini dapat masuk kedalam kuali melalui dindingnya yang berpori halus karena terbuat dari tanah liat. Sedangkan pada panci aluminium ataupun stainless steel merupakan penghantar panas yang baik sehingga proses memasak makanan akan lebih cepat. Namun cita rasa yang dihasilkan kurang mantap. Saat ini sudah jarang sekali penggunaan peralatan dapur tradisional untuk memasak, apalagi di perkotaan. Hal inilah yang menjadi inspirasi para pengusaha dibidang kuliner untuk mendapatkan pangsa pasar dalam mengembangkan usahanya dengan mendirikan restoran yang bernuansa tradisional. Ternyata banyak konsumen yang tertarik dan senang menikmati hidangan yang disajikan pada restoran tersebut.

\section{b. Lebih aman bagi pengguna dan ramah lingkungan}

Penggunaan peralatan memasak modern ternyata memiliki dampak yang kurang baik bagi penggunanya. Misalnya saja penggunaan kompor gas ataupun kompor listrik, jika tidak hatihati ataupun lalai akan membahayakan karena gas LPG yang digunakan sebagai bahan bakar dapat meledak. Begitu pula dengan pemakaian alat memasak modern yang menggunakan listrik, jika tidak hati-hati dapat terjadi konsleting listrik yang membahayakan. Selain itu penggunaan alat-alat memasak yang berasal dari aluminium, plastik ataupun melamin akan berdampak buruk bagi kesehatan. Kandungan bahan kimia tersebut akan terakumulasi dalam tubuh sehingga dapat mengganggu kesehatan manusia. Perkakas memasak yang berasal dari peralatan tradisional akan lebih terjamin dari sisi kesehatannya karena tidak ada kandungan bahan kimia berbahaya pada bahan baku maupun proses pembuatannya. Peralatan dapur tradisional juga dinilai lebih ramah lingkungan. Apabila rusak misalnya retak ataupun pecah, akan mudah terurai kembali ke dalam tanah sehingga tidak mencemari lingkungan. Berbeda dengan peralatan dapur modern yang berasal dari plastik, melamin, dan yang lainnya, apabila telah rusak sampah yang ditimbulkan tidak dapat terurai di dalam tanah sehingga akan menyebabkan pencemaran lingkungan.

\section{c. Lebih ekonomis}

Memasak dengan menggunakan peralatan dapur tradisional lebih menguntungkan karena akan dapat menghemat biaya kebutuhan rumah tangga. Harga peralatan dapur modern lebih mahal dari pada peralatan dapur tradisional. Selain itu biaya operasional yang dikeluarkan jika menggunakan peralatan dapur modern juga lebih mahal. Sebagai contoh jika rumah tangga menggunakan kompor gas ataupun kompor listik, maka biaya yang digunakan untuk membeli peralatan tersebut lebih mahal dibandingkan dengan rumah tangga yang menggunakan anglo atau tungku untuk memasak. Dalam pengoperasiannya, kompor listrik maupun kompor gas membutuhkan bahan bakar yang lebih mahal apalagi dengan semakin tingginya biaya penggunaan listrik dan 
naiknya harga gas LPG. Sedangkan pada penggunaan anglo atau tungku biaya yang dikeluarkan relatif murah karena bahan baku pembuatannya berasal dari lingkungan sekitar dan biaya untuk pengoperasiannya relatif murah. Rata-rata dalam sekali memasak hanya membutuhkan satu kilogram arang jika menggunakan anglo. Sedangkan untuk tungku menggunakan kayu bakar yang jumlahnya juga relatif sedikit untuk keperluan memasak rumah tangga per harinya. Kayu bakar dan arang tersebut mudah diperoleh di lingkungan sekitar tempat tinggal ataupun jika membeli harganya tidak mahal.

\section{d. Melestarikan tradisi nenek moyang}

Penggunaan peralatan dapur tradisional merupakan salah satu wujud pelestarian budaya yang diwariskan nenek moyang kita terdahulu. Sebagian besar peralatan dapur tradisional berasal dari tanah liat yang umumnya dinamakan kerajinan gerabah. Tradisi pembuatan seni kerajinan gerabah ini merupakan tradisi masa lalu dalam perkembangan kebudayaan manusia (Ambar, 1977:1). Telah berabad-abad tanah liat digunakan sebagai bahan baku yang digunakan untuk membuat peralatan rumah tangga melalui teknik sederhana (Hildawati, 1990/1991:156). Kegiatan ini tercipta sebagai salah satu usaha manusia untuk mengatasi kesulitan dalam kehidupannya, yang berkaitan dengan perlunya wadah yang berfungsi sebagai tempat untuk meletakkan bahan makanan, alat masak, dan lain sebagainya (Sumijati, 1994:302). Berbagai penemuan artefak yang merupakan sisa benda-benda di masa lampau ini merupakan bukti adanya kemampuan manusia dalam usahanya untuk memenuhi kebutuhan hidupnya. Penemuan terakota (gerabah) dari Trinil, Sangiran, menunjukkan kemampuan nenek moyang kita di masa lampau dalam berolah seni, termasuk dalam menghiasi barang yang dihasilkannya (Gustami, 2008:24). Meskipun hanya berupa pecahan-pecahan teracota namun hasil temuan tersebut mengisyaratkan betapa budaya bangsa ini sejak masa lalu telah timbul budaya yang agung atau budaya yang adiluhung. Oleh karena itu upaya pelestarian budaya sangat diperlukan untuk tetap mempertahankan budaya yang diwariskan oleh nenek moyang kita terdahulu salah satunya dengan tetap menggunakan peralatan dapur tradisional ini dalam kehidupan sehari-hari. Kita boleh saja mengikuti perkembangan iptek, namun tidak serta merta menghilangkan budaya tradisional bangsa ini. Tujuannya agar para generasi yang akan datang masih dapat mengenal ataupun melihat berbagai jenis peninggalan nenek moyang mereka terdahulu. Hal-hal kecil dapat diterapkan dalam kehidupan sehari-hari, misalnya saja bagi para ibu dapat memperkenalkan kepada anaknya mengenai pengetahuan peralatan memasak tradisional terutama bagi anak perempuannya. Di dunia pendidikan perlu diberikan mata ajar mengenai berbagai peralatan memasak tradisional, sebagai contoh jurusan tata boga yang didalamnya disisipkan pelajaran mengenai penggunaan peralatan dapur tradisional. Hal tersebut merupakan salah satu bentuk usaha sosialisasi bagi anakanak dalam mengenal lingkungan dan budayanya. 
PENUTUP

Peralatan dapur tradisional merupakan peralatan yang bersifat tradisional yang diturunkan oleh nenek moyang kita terdahulu. Hal yang berhubungan dengan tradisional ini merupakan suatu bentuk yang unik dan sepantasnya dijaga kelestariannya sebagai warisan budaya bangsa. Perkembangan teknologi saat ini dapat mendesak unsur-unsur tradisional yang dikhawatirkan akan dapat menghilangkan tradisi ini, sehingga generasi yang akan datang tidak dapat menikmati bahkan untuk sekedar mengetahuinya saja. Jiwa nasionalis sangat diperlukan dalam upaya pelestarian budaya tradisional ini. Generasi yang memiliki jiwa nasionalis akan menganggap bahwa melestarikan budaya merupakan suatu kebanggaan bukan paksaan. Berdasarkan hasil penelitian beberapa jenis dan fungsi dari peralatan dapur tradisional dapat diuraikan dalam penelitian ini antara lain: tungku, dandang, belanga, wajan, kendi, parutan kelapa, tempayan, irus, centong, serta cobek dan ulekan. Peralatan dapur tradisional mengandung nilai budaya yang sampai saat ini masih berkembang di sebagian masyarakat kita. Berbagai manfaat juga dapat diambil dari penggunaan peralatan dapur tradisional yang tentunya akan menguntungkan bagi pemakainya, mulai dari harganya yang lebih ekonomis, ramah lingkungan, cita rasanya lebih enak serta dapat melestarikan tradisi nenek moyang. Sejalan dengan perkembangan iptek, saat ini peran peralatan dapur tradisional ini ada yang mengalami perubahan dari alat bantu untuk memasak menjadi asesoris hiasan ataupun sovenir tamu. Peran berbagai elemen dalam masyarakat sangat mempengaruhi eksistensi keberadaan peralatan dapur tradisional dalam kehidupan masyarakat. Selain jiwa nasionalis yang dimiliki oleh masyarakat, peran pemerintah juga sangat diperlukan dalam pelestarian budaya yakni sebagai pelindung, pengambil kebijakan, fasilitator yang mendukung pelestarian budaya bangsa. Harapannya agar budaya asli bangsa Indonesia dapat dipertahankan agar tidak di klaim sebagai budaya bangsa lain. 


\section{DAFTAR PUSTAKA}

Ambar, Astuti. 1977. Pengetahuan Keramik. Yogyakarta: Gajah Mada University Press.

Ambar, Astuti. 2008.Keramik: Ilmu dan Proses Pembuatannya.Yogyakarta: Jurusan Kriya Fakultas Seni Rupa ISI Yogyakarta.

Aristanti. 2001. Asia Industrial and Institutional Stove Compendium. Yogyakarta: ARECOP.

Astuti, Septiana. 2012. Kajian Makna Lesikal Peralatan Rumah Tangga Tradisional di Pasar Gedhe Klaten (skripsi). Yogyakarta: Program Studi Pendidikan Bahasa Jawa Jurusan Pendidikan Bahasa Daerah Fakultas Bahasa dan Seni Universitas Negeri Yogyakarta.

Hildawati, Sidharta. 1990/1991."Seni Keramik Modern" dalam Muchtar Kusuma Atmaja, et al., Perjalanan Seni Rupa Indonesia:Dari Zaman Prasejarah Hingga Masa Kini. Bandung: Panitia Pameran KIAS 1990-1991.

Gustami. 2008. Nukilan Seni Ornamen Indonesia. Yogyakarta: Jurusan Kriya Fakultas Seni Rupa ISI.

Moleong, Lexy.2003. Metode Penelitian Kualitatif. Bandung: Remaja Rosdakarya.

Mulyono, G. 2009. Kajian Ergonomi Pada Tungku Masak Dapur Tradisional Masyarakat Desa Sukorejo Kediri. National Conference Applied Ergonomics 2009. Surabaya: Jurusan Desain Interior Fakultas Seni dan Desain Universitas Kristen Petra.

Nawawi, H. 1983. Metode Penelitian Sosial. Yogyakarta: Gadjah Mada University Press.

Poesponegoro, M. dan N. Notosusanto. 1984. Sejarah Nasional Indonesia IV. Jakarta : Balai Pustaka.

Sartono, Kartodirdjo, dkk. 1975. Sejarah Nasional Indonesia. Yogyakarta: Gajah Mada University Press.

Setyawan, Abi Dharma Bakti. 2009. Analisis Morfo-Semantis Nama Peralatan Dapur di Kabupaten Pemalang (Skripsi). Yogyakarta: Program Studi Bahasa Jawa Jurusan Pendidikan Bahasa Daerah Fakultas Bahasa dan Seni, Universitas Negeri Yogyakarta.

Sulaiman, N., R. Sufi, A. H. Rasyid. 1993/1994. "Peralatan Dapur Tradisional Aceh". Daerah Istimewa Aceh: Departemen Pendidikan dan Kebudayaan Bagian Proyek Pembinaan Permuseuman.

Sumintarsih, 2006. "Pawon Dalam Budaya Jawa". Jurnal Sejarah dan Budaya Vol 1, No.1, Juni 2006. Yogyakarta: Balai Kajian Sejarah dan Nilai Tradisional, HIm. 20.

Sumijati, Atmosudiro.1994. "Gerabah Prasejarah di Liang Bua, Melolo, dan Lewoleba". Disertasi untuk memperoleh derajat Doktor dalam IImu Sastra pada Universitas Gajah Mada Yogyakarta.

Sumintarsih, dkk. 1990/1991. Dapur dan Alat-Alat Memasak Tradisional DIY. Jakarta: Departemen Pendidikan dan Kebudayaan. 


\section{INTERNET}

http://melayuonline.com/ind/culture/dig/2612 diakses tanggal 4 Agustus 2014. http://tembi.net/selft/0000/jawa/anglo.htm diakses tanggal 10 Agustus 2014. http://arsip.tembi.net/id/news/bale-dokumentasi-aneka-rupa/dandang--spesialisuntuk-adang-nasi-4293.html diakses tanggal 5 Agustus 2014.

http://penjaskesehatan.blogspot.com/2013/10/memutihkan-gigi-dengan-abu-gosok. html diakses tanggal 6 Agustus 2014.

http://dermaji.desa.id/2013/06/10/dandang/ diakses tanggal 2 Agustus 2014.

http://id.wikipedia.org/wiki/Kendi diakses tanggal 5 Agustus 2014.

http://bebibluu.blogspot.com/2014_06_01_archive.html diakses tanggal 5 Agustus 2014. 